THE ROCKY MOUNTAIN GOAT

QL

737

U5GT3

\author{
BY \\ MADISON GRANT
}




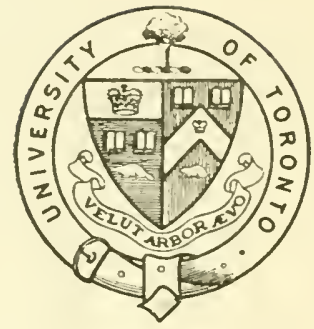

The IJ. Th. Tưrrell Tlithrary

Diequeatlipet to the

Hhuiuersity of Tornutn Tlithary

tug

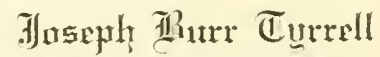

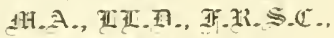

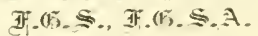

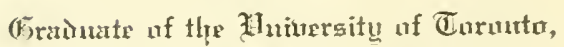
ani) puineut (Couthia genlngist, explurer, antis selyulate 
Digitized by the Internet Archive in 2008 with funding from Microsoft Corporation 

THE ROCKY MOUNTAIN GOAT 


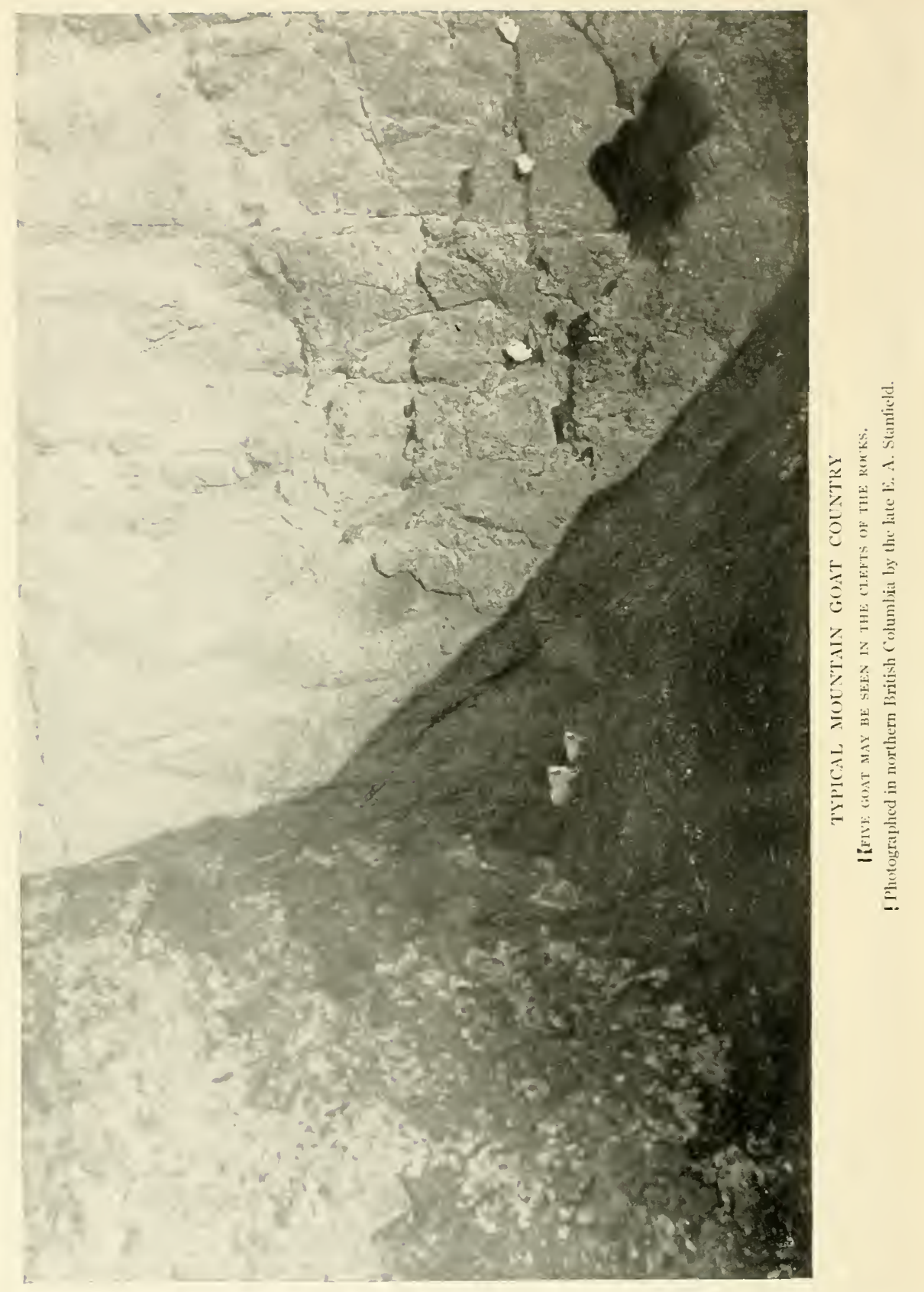




\title{
THE ROCKY MOUNTAIN GOAT
}

\author{
by \\ MADISON GRANT
}

SECRETARY OF THE NEII YORK BOOLOEICAL SOCIETY

REPRINTED FRU.1I THE NINTH ANNUAL REPORT

(IF THE.

\section{foru Dorti Foological Eocicty}

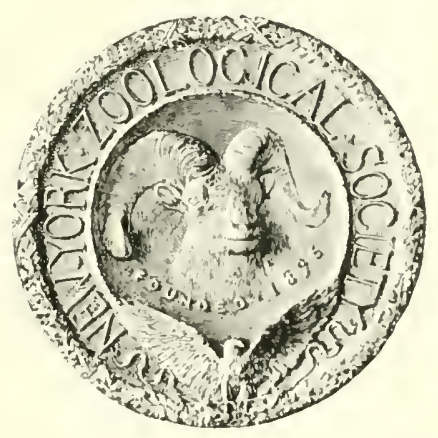

NEW YORK

OFFICE OF THE SOCIETY, 11 WALL, STREET 1905 
QL

456.73

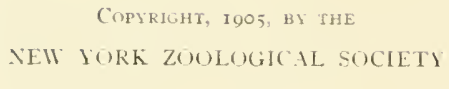

$\frac{6+7 \cdot 3051}{11 \cdot 2 \cdot 5 \cdot 8^{2}}$ 


\section{Ilist of Tllustrations}

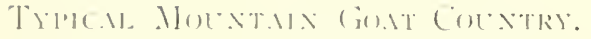

P.IGE

Frontispiece.

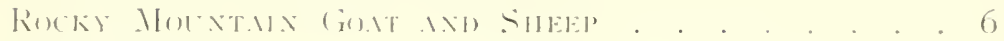

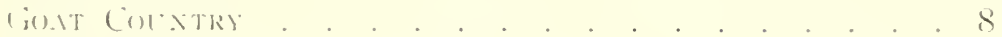

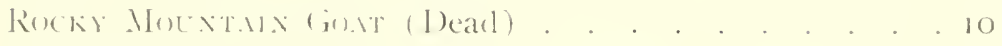

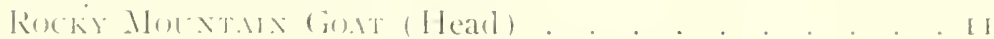

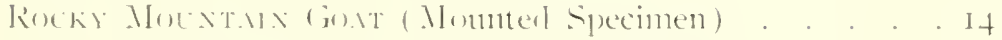

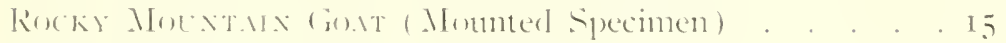

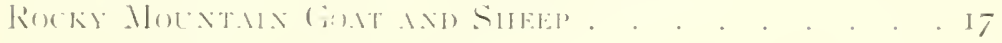

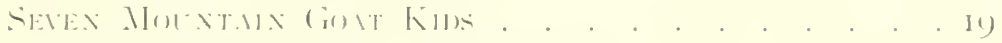

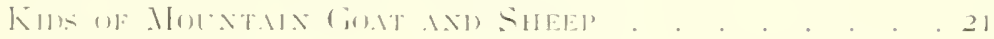

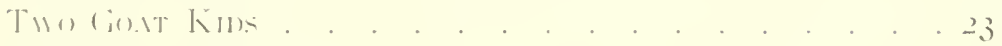

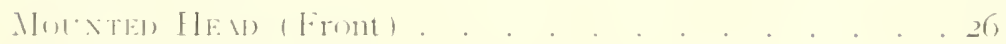

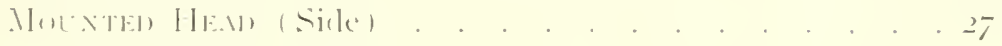

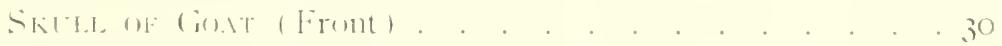

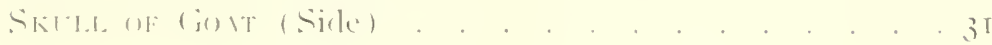




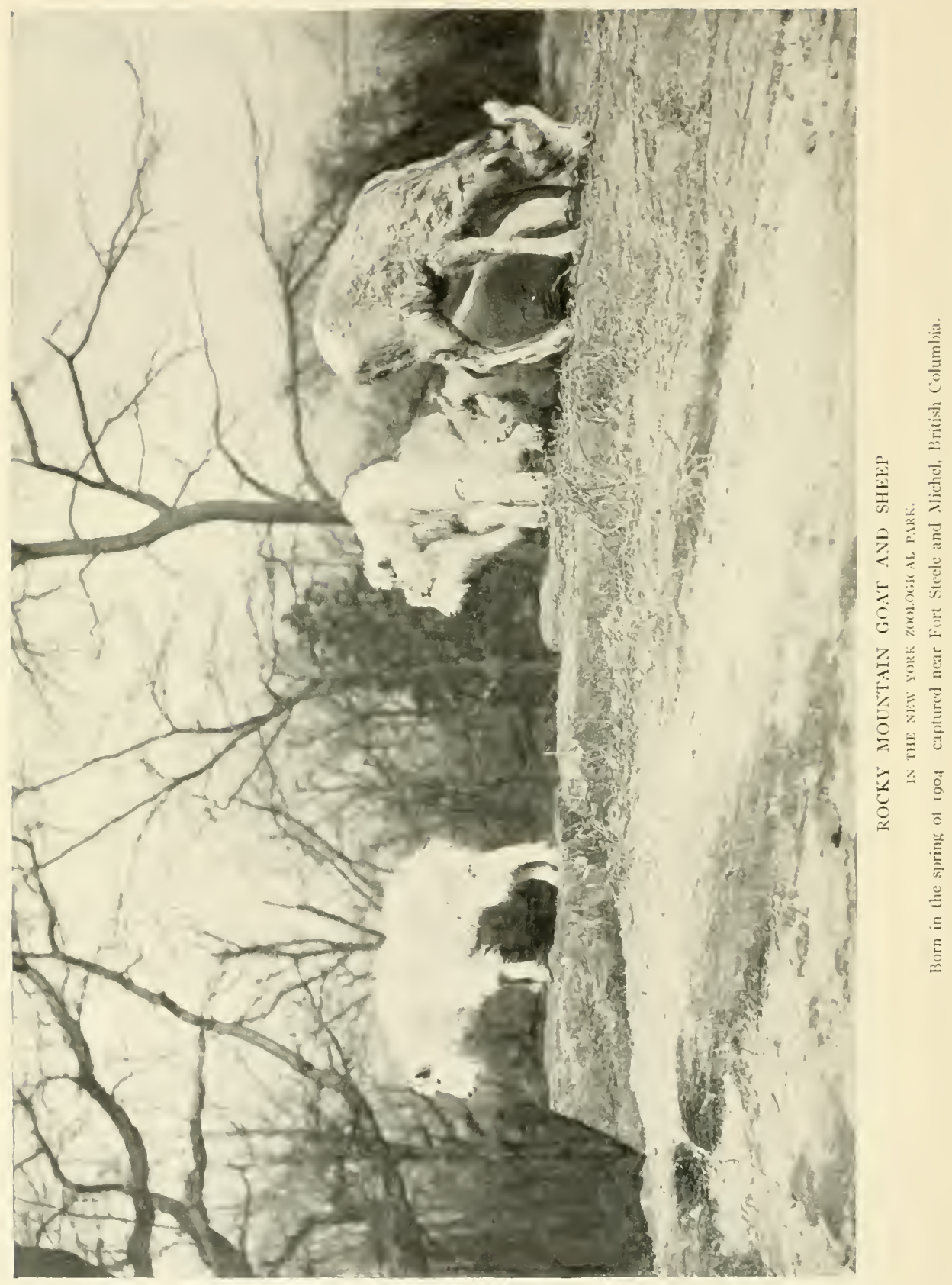




\title{
THE ROCKY IOUNTAIN GOAT.
}

\author{
By $\| \mathrm{AIISONGRANT.}$
}

T

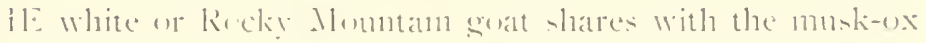
the huner of being the least linowin of the exance animals of North Ameriea anel rescrigtions of it written even as recently. as tem vears ago are valueless, as in many cases this animal is comfused with white menntain sheep and even with deers. The explanation of this lack of knowledere lies in the extremely remote and inacecsible babitat of the woat. which begins in the northwesteru [nited States, amonger the highest peaks of the Rocky Momotains and of the coast ranges and extencls north, thromgle liritisle (iolumbia, intu Alaska. The material in most nat unal histories, relating to this animal, is seanty and based (on very inalecpate informations, since the oppostminty to see and hunt it has not leen granted (o) manys. ln captivity. We have hat, on the . Itantic eóst, only oight immatme specimens,

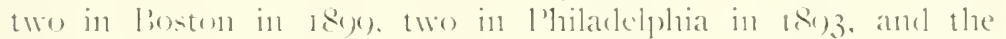

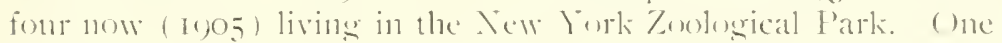
well grown male is living at this time in the Lemelom Zonlogical (iarklem.

As a result of this searcity of direet kmowledece many myths have gathered aromed this menutain dweller. leating, as usual in our Xortle American game animals. to an alomelanee of inappropriate names. The name "encate" is olojectionable. but will

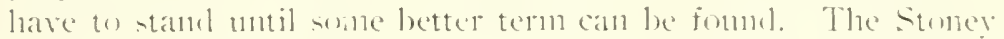

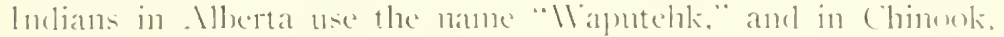
the nuiversil jargem of the Northwest, the goat is called snow Mawiteh (white leer). Neither of these terms are likely to becomle commonus. It is sut a gent, nor even closely related to themen. but is the sole representative on this continent, of a very aberant

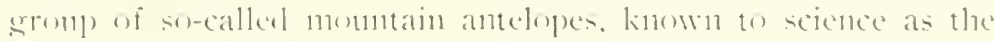
Rupieaprince, a Subfanily of the Boride.

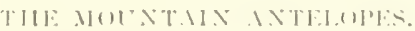

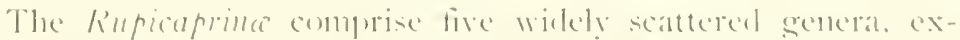

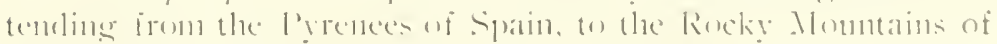

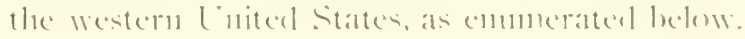




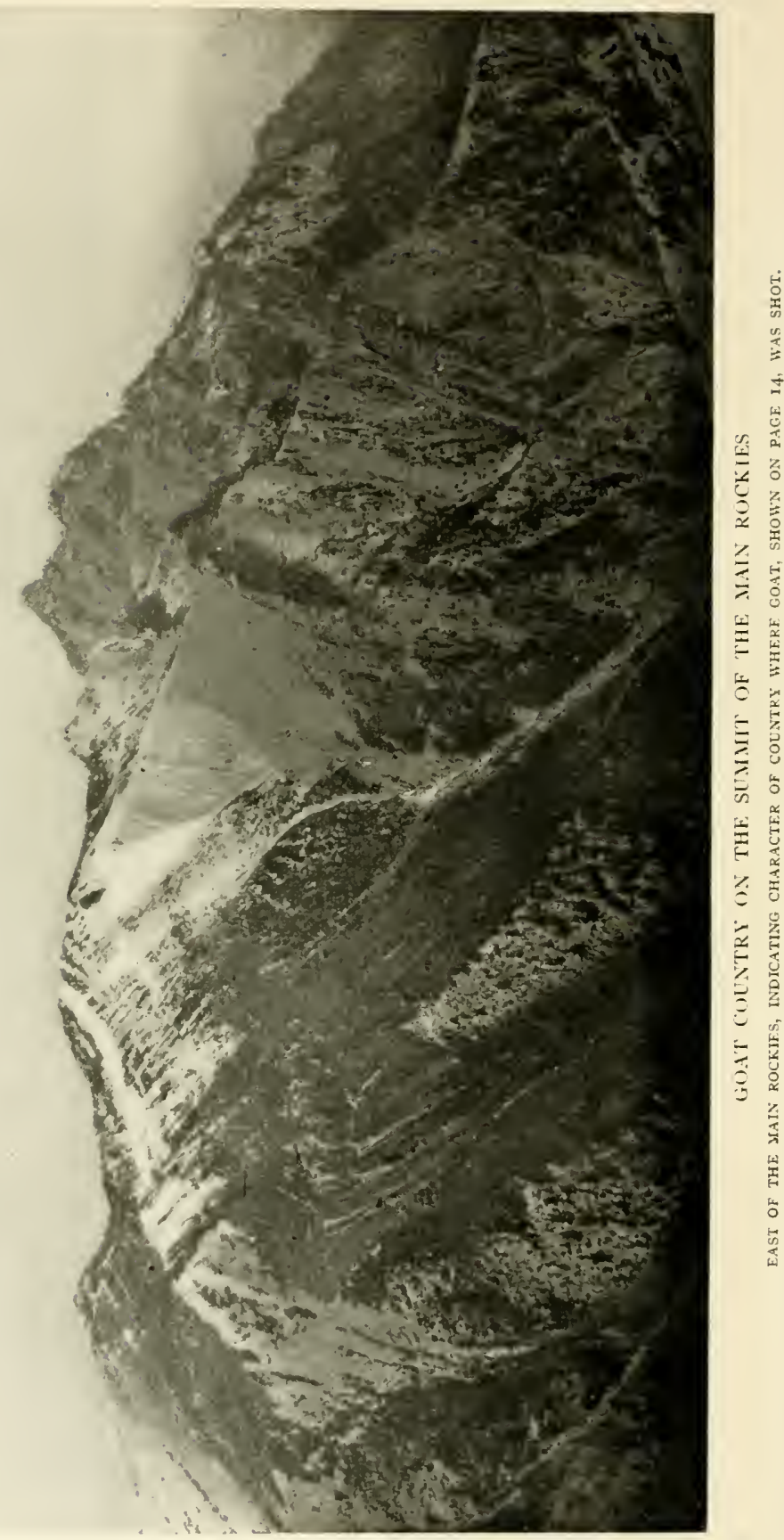




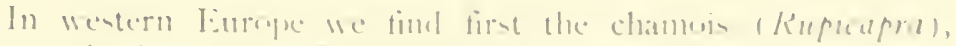

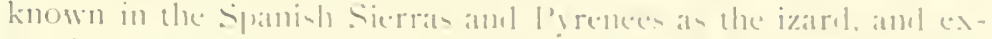

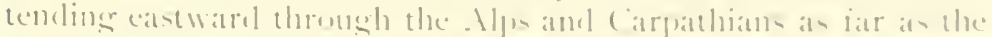

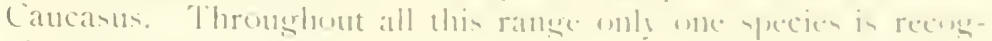
nizerl.

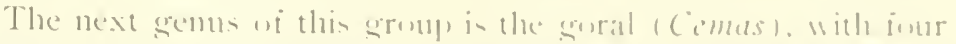

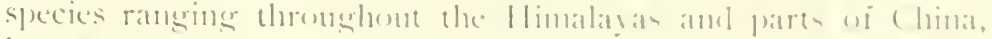
into Amurland.

In Tibet wc have the thirl and hecidedly most alerrant mem-

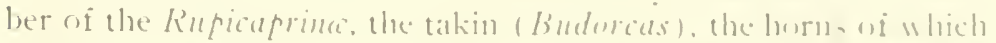

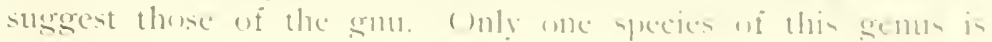
known.

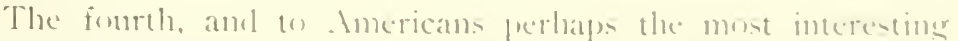
Old IVorld member of this sublamily, is the scrow t lamer-

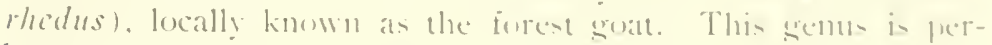
haps, more closely allicel on () reammos than amy of the precerling

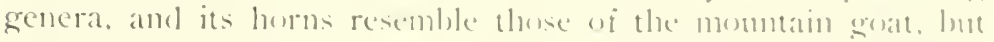

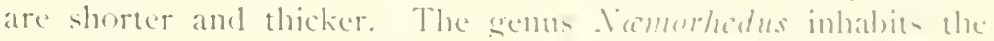

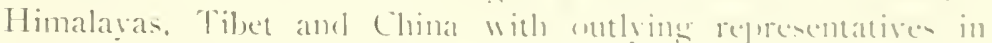

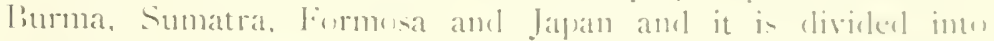
numeroms species. The fifth aroms is Orommos, the subject wi this article.

All the members of these genera resemble the sorat in touth structure, but differ wielely from them in the position and shatpe of the horns, face elands and wher impontane details. The whole group) is to be regarded at an eaty off-shone of the Borida, to some extent intermediate leetween the garts am the true bovine antelopes. The Kupicaprine must hase pushed north, with their not distant ally the musk-ns, at a rery catrly time and become adjusterl to alpine and loreal comblitions. is the close of the glacial perion mans of its members decerted the low comury and retired to high altitules so that in some instances, notably that wi the chamois, we hate an example wi

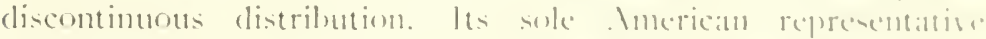

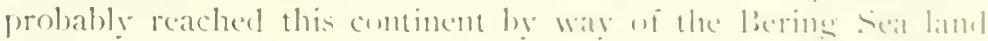

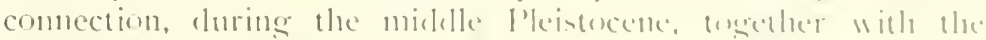
other American sencea of the Buside.

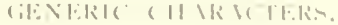

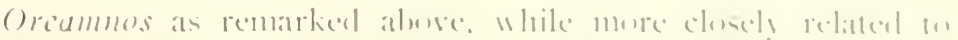

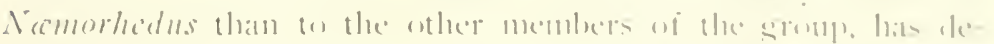
parted widely in structure irom all wi its relatione le $110 \mathrm{~m}$ 


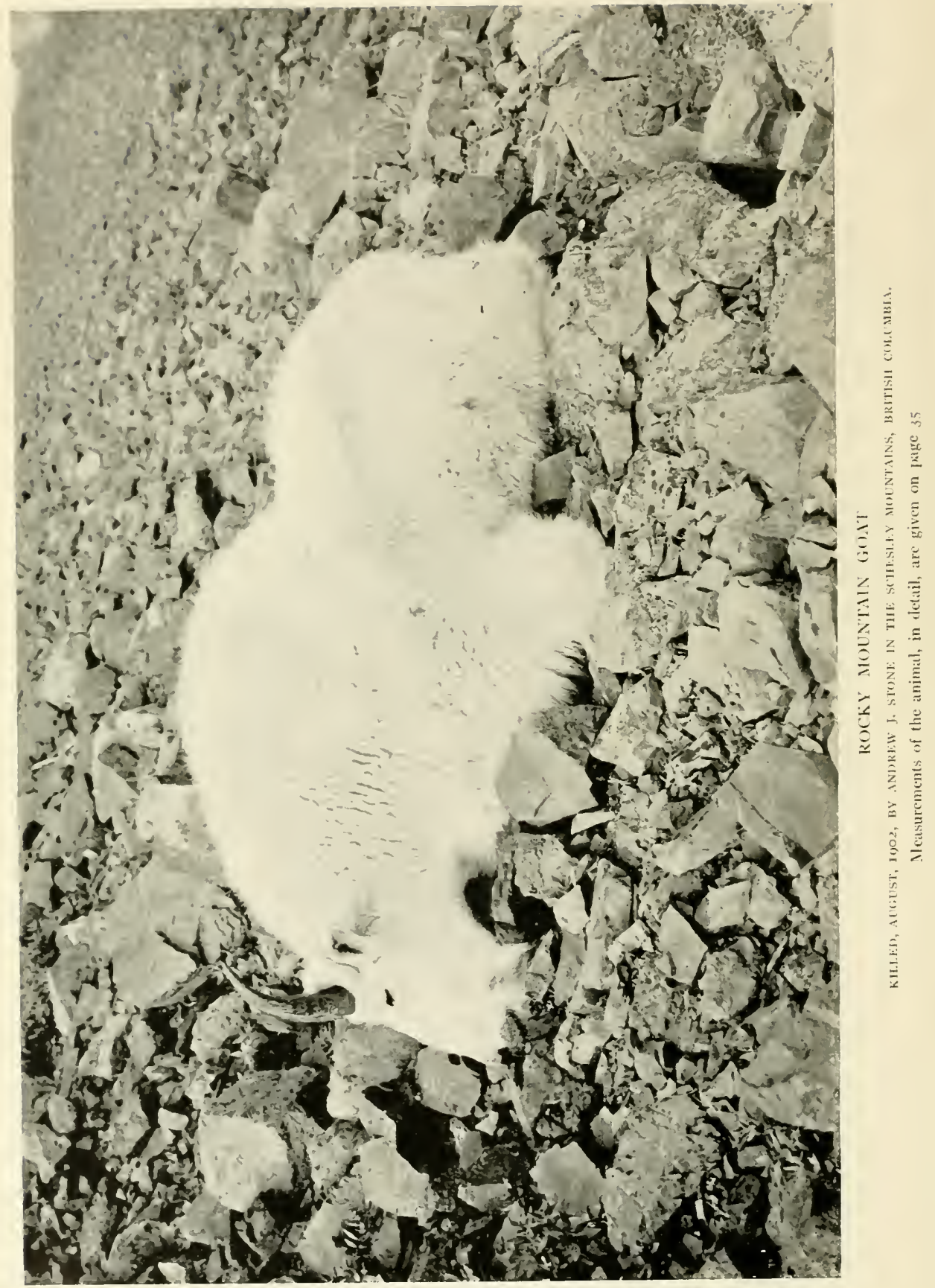




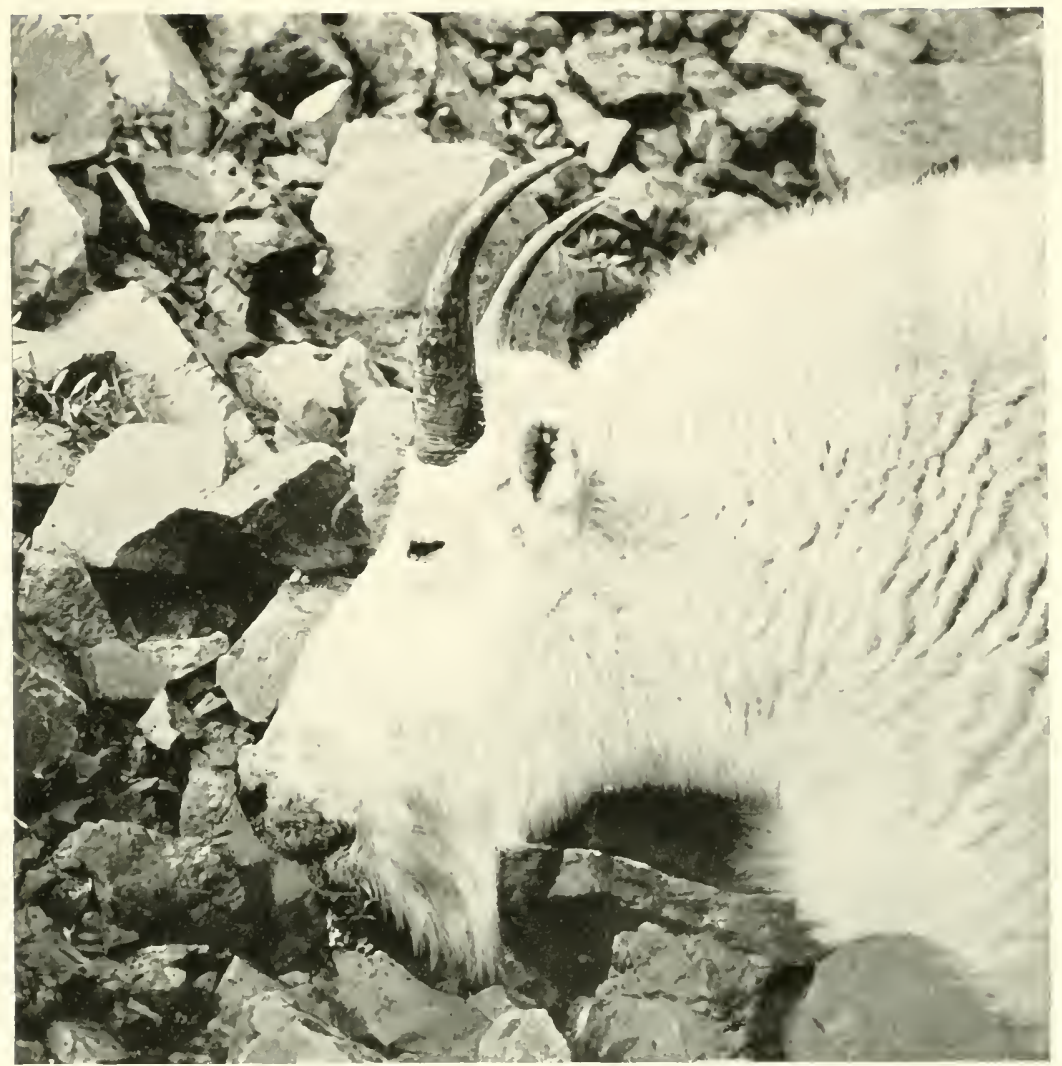

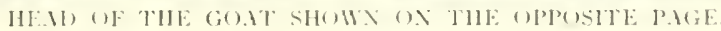

striking character is its almost pure white coat. 'This coloring is in perfect harmony with an enviromment of smow fields, but in some parts of its range it renclers the animal mnecessarily eomspicuons. Entil white ment appeared on the secme, it macle very little difference to the guat whether his enemies could sec him or not, as his lome was beyonel the reach of pumas, wolves, and for the most part of bears and until oflere game beane searee, the Inclians diel not hunt this inacessible peak-elweller for closely. All the diges of Oremmos are characterized by this white coat and the only exception is the well anthenticated acentence of goat in the Selkirlis of southern liritish Colmmbia. with a clearls-

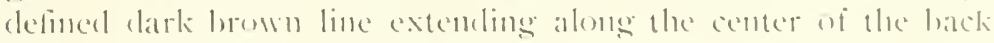
and terminating in an almost black tail. This colote variation 
appears to be fixed in both the stmmer and winter pelage, as the markings were fonnd on the skins of goats killed both in July and November. Reports of goat with these characters are widespreat along the upper Columbia River, so that it would seem as though toward the southern limit of its range, a color variation were just beginning to appear. In acklition to its uniformly white color. Orcamnos differs from the serow in the prominence of its eve sockets, in the elongated shape of the muzzle and face, in the position and shape of the horns and more particularly in the cannon bones, which are exceptionally short and stout. In this latter respect Oremmnos leparts widely from all the other members of the Rupicuprinc. The most striking character however, of Orammos, is the presence, situated in a half circle immerliately behind each horn. of a large, black scentgland, as large as half an orange. This gland is sometimes so tongh as to wear cleeply into the base of the horn. A horn worn away in this mamer was securerl by the writer in British Columbia.

The comparatively short duration of time since the appearance of Ordmmos in America and the somewhat uniform character of its habitat, probably aceount fo: the absence of much type variation.

TYPES OF OREAMNOS.

The first specimens of the monntain goat to be described, came from the Cascade Momntains on the Colmmbia River in Oregon and of course now stand as the type of Oremmos montums, having been first describer by Rafinesque in $I_{I}$ T. This subspecies is intermediate in size between the eastern form of American goat, O.m.missonle. and the large Canadian O.m.colmmbimms, and, is characterized by a short but broad skull. The true Oreammos montams extends from about the Canadian boundary. south throngl Washington into Oregon. In the '70's a considerable number were found on Mt. Ranier in Washington, and they still occur on .It. liaker to the northward. It is absent. however, from the Olinmpic Monntains, from Vanconver Island and from the sonthern Cascades in Oregon. Nothing is known of the northern limits of this subspecies, but it probably does not extend very far into British Columbia, merging at that point into $0 . \mathrm{m}$. colmmbinnus. The most southerly (Oregon records that the writer has been able to obtain is Mt. Jefferson in that State. latitude $44^{\circ}$ fo' north, in approximately the same latitule as the Sawtooth Momntains in Trlaho. 
Probably the only place where the goat exists to-day in the State of Orexon is the momntains in Mallowa County, in the extreme northeast cormer of the State, and the animals from that lexalits are probably to he referred to O.m.missonle. Ther have lomes since vanishert from Mt. Hoorl and from the other peaks in the western part of the State, where they ence aboumeled. In the State of Washington they exint in reduced numbers from the Canadian boundary as far south as Nlt. Nolans, although at the latter point they are posibly now extinct. Througlout the State the frefuency of mames, sich as "goat rocks," "goat paths," "grat buttes" and "woat crecks," testify to tleir carly abundance, and they were formerly shot from the decks of steamess on Lake Chelan by hunters who took a wanton delight in secing the wommerl animals fall down the preeipitous banks.

In the Mt. Ramiere lorest Reserve they are fonul in small 11mmlers. In the isolated rolcanic peaks along the coast the goat is tou easily reached to be allowed to survive, and it is probable that before many vears the interesting animal will be entirely exterminated in the Lnited Sitates exeept in the main Rockies.

The Alaskan form, at the extrene western linit of the genus, in the neighlorhoml of the Mlt. St. Elias . Mps and the Coprper River, was (lescriberl by Dr. D). G, Ellot, in Iooo, as a second and valjel species, nunder the name of () redmmos kennedyi. It is stromgly characterized by the lyate shape of the horss and certain anatomical features.

These two were the only describerl forms. until nof. when the altention of 1)r. I. A. Allen, of the American Mlusenum of Natural Histery, wats called hy the writer to the great difference in lulk of body and size of horms of the goat of Rritish Columbia, and those of the Bitter Rout Momutains in Nentana. Ljon comparing a number of specimens from the Cascade Nomntains. the type locality of Oreammes montamms, from the bitter Root Nomntabus of Mfontana and loblon, frome the main Rockies in southern liritish Colmombia and from the sebesley Mountains of werthern liritish (olmmbia, it was fommel that all these specimens

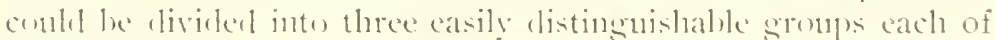
sulspecific ramk.

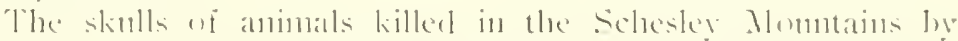
Andrew I. Stone in mo3. were found to be in all respects identieal with those killed by the writer and Mr. Charles Arthur

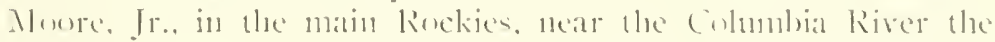
following rear. Amimals from these districts were chatratere ized by great bulk and ly a lome and relatively narrom stall. 


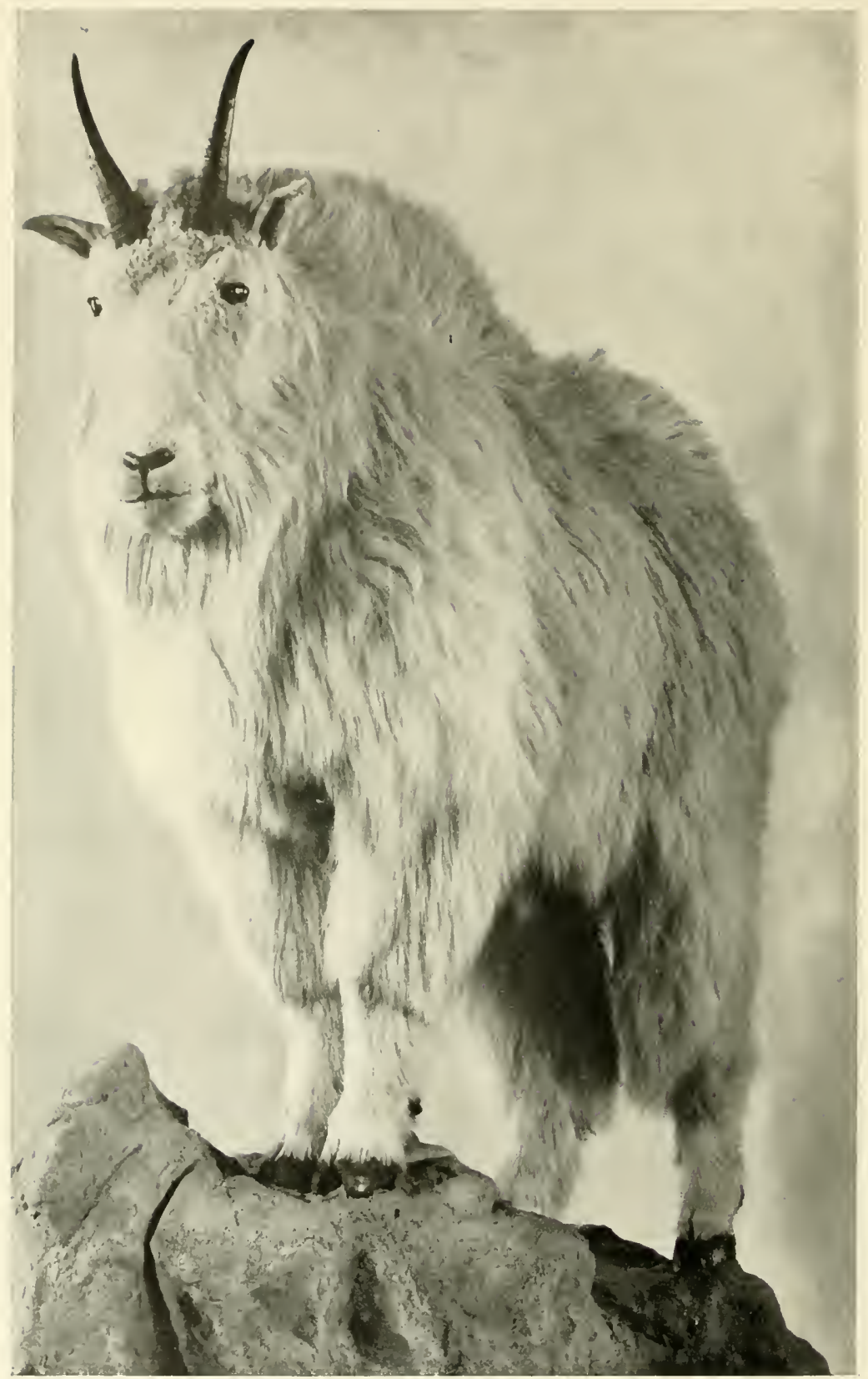

ROCKY MOLNTIIN GOAT

KIILED IN SPILIAMACHENE VALLEY, SOETH OF GOLDEN, BRITISH COLCMBI., NOVEMBIR. I0O3

Total length with tail, following convolutions of body, 73 inches; tail, 7 inches; hind foot, 12 inches height at shoulders, $4 \mathrm{I}$ inches; measurements taken after mounting. On exhilition in the American Mluseum of Natural History. 


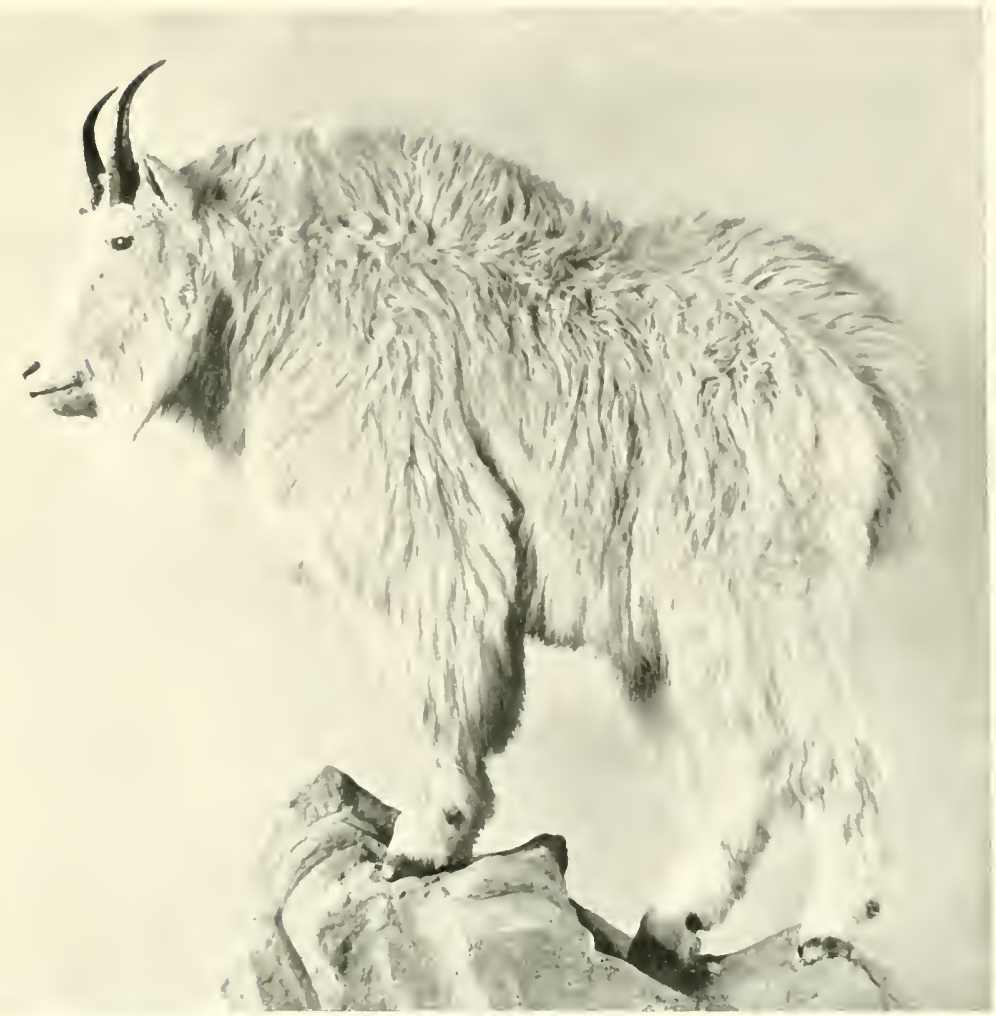

SIIE WHW GF SPECIMLX SHOWT UN OPPOSITE PMEF.

This was the thire tope described and it received from Dr. Alien the name if O.mecolmmbiums. This subspecies probably extends from the American borkler up through the Canalian Rockies, to the northern limits of goat in that region. which is west of the Mackenzic River at alust north latitule $6330^{\prime}$. The goat in the morthern Rockies, may possibly be fommel to be specifically distinct from the goat on the coast of somthern Maska.

In the midst of the distributional area of this larese subspecies and in the vicinity of the Pig liend of the Columbia River, a very small goat is fommel. This amimal. npon further investigation. may prove interesting. It present. howerer, all the Canadian gonats must be provisionally assigned to ().mecolmmbiamms.

A curions break in the range of this subspecies is fonmel just north of the Liand River, where, aceoreling to no kess an auther- 
ity than Andrew I. Stone, no goat are found for a distance of over a hundred miles. Probably the local topography, of which we have no knowledge, will explain the absence of goat from this territory. No goat have yet been found north of the Jukon River.

O.m.columbiumus abounds along the coast ranges of British Columbia, and extends into Alaska, probably merging in the neighborhood of the Copper River into O. kennedyi, the westernmost nember of the genus. The extreme western record for goat is the Matanuska River, not far from the head of Cook Inlet. Horns from this locality, however, do not show the characteristics of Kemnedy"s goat. No goat are reported in the vicinity of Mt. McKinley, but they are found along the Copper River for a considerable distance inland, and there is some evidence of their oceurrence on the north side of Mit. St. Elias. It may be well to remark here that while $O$. kenned $y i$ is a valid species, founded on abundant material, no living specimens have been seen by a white man so far as is known, nor have we any information concerning the limits of its distribution. O.m.columbianus is by far the largest and handsomest member of the genus, unless $O . \mathrm{ken}$ nedyi proves on further investigation, to excel in these respects. It is, therefore. surprising that the great differences in size and other characteristics, which distinguish this type from the goat in the United States have not been previonsly recognized.

The animals south of the Canadian border and still in the main range of the Rockies, upon comparison with the preceding types. were found to be much smaller, in fact the smallest of all the subspecies and were characterized by shorter but still relatively narrow skulls. The specinens of this type under consideration laving been killerl in the Bitter Root Mountains, the subspecific name of O.m.missoula was given them by Dr. Allen. This is the fourth and last type to be described, although these animals from the Bitter Root Mountains were the first goat known to transcontinental explorers. This is the goat usually hunted by American sportsmen and its range probably extends from the southeastern limits of the genus in Montana and Idaho to the Canadian border, where like $O$. montanus it passes imperceptibly into O.m.columbianus. The extreme southerly limit of the goat in the Rockies is the Sawtonth Mlountains and the Salmon kirer in Idaho. It does not reach the Tetons, in Wyoming, nor does it occur in the Yellowstone Park. The question of its absence in these localities will be discussed later in this paper.

To sum up, the two American subspecies are smaller than their 


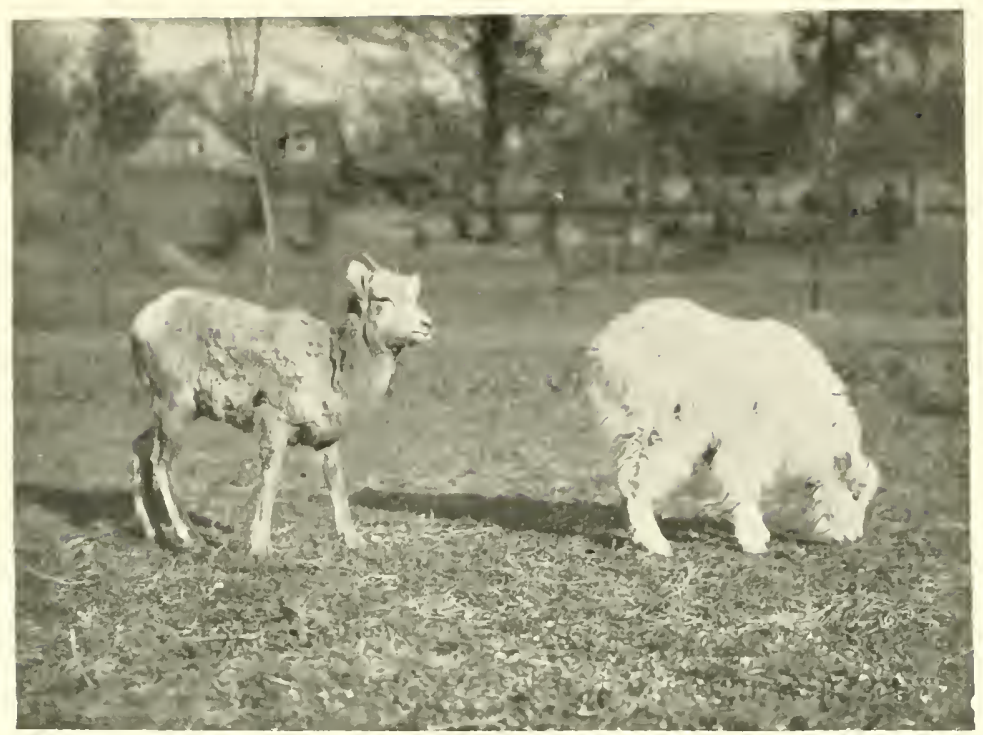

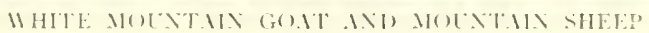

IN THE YEUI YORh ZOOIOX,IC II. PARh.

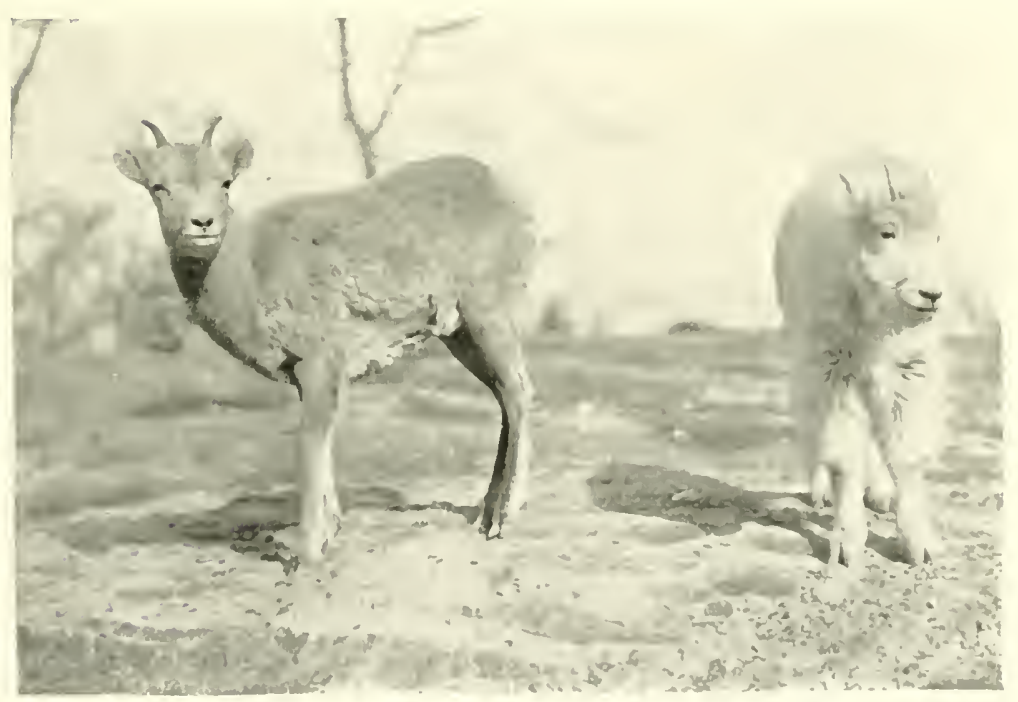

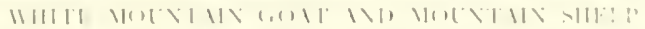

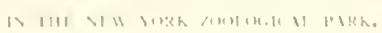


Canarlian relatives and the type from the Cascarle Monntains possesses a brual skull, in direct contrast to the narrow skulls of all other goats. buth Anerican and Canarlian.

\section{C.ILSES GUERNING HATRIILTION.}

The distribution of the genus is limited by the claracter of the nnountain ranges, rather than any other consileration, and tow much emphasis cannot be placed on the fact, that of all our North American animals the white goat is the only onc absolutely confined to precipitous peaks and ridges, which even the mumtain sheep) scliom approach.

The extrente north and south ranges of Oreamnos in the main Rockies present several problems of great interest. The southern limit is clearly martied by a change in the formation and rugeedness of the monntains themselves. which, together with climatic conditions, and the lack of water in summer on the niountain tops. are sufficient to acconnt for the absence of these animals nuch sonth of their present limit. I very different condition prevails in the north. At the extreme northern limit which is about $63^{\circ} 30^{\prime}$, the monntains begin to lose their height but are still of considerable size and quite rugged enough to provide a suitable home for Orommos. White sheep are fouml all through these mountains, up to the very coast of the Aretic Ocean and westward through the Romanzoff Monntains in northern Alaska. These sheep are certainly not better equipped to resist aretic cold than are the goat, so we must seek for some canse other than climatic or topographical conditions. There must be sonne unkunow and unfavorable condition of food supply which prevents Oremmos from reaching the extreme north. This is perhaps the most interesting and difficult of the problens affecting the distribution of the genus.

Along the Pacific coast of the Lnited States the momntains are not sufficiently precipitous to attract the goat, and consequently that animal is fonnd only at some distance inland, but in northWestern Diritish Colmmbia and sonthern Alaska, the Rockies approach the coast in stupendous cliains. Which swing westward through the Mt. St. Elias range. Through all this conntry the suat occupies the coast region from I'rince William Sound south nearly to the American border. They are not foumd in any of the arljacent islands.

Along these coast ranges goat are nuch more numerous than in the main Rockies, owing probably to the presence of forests 


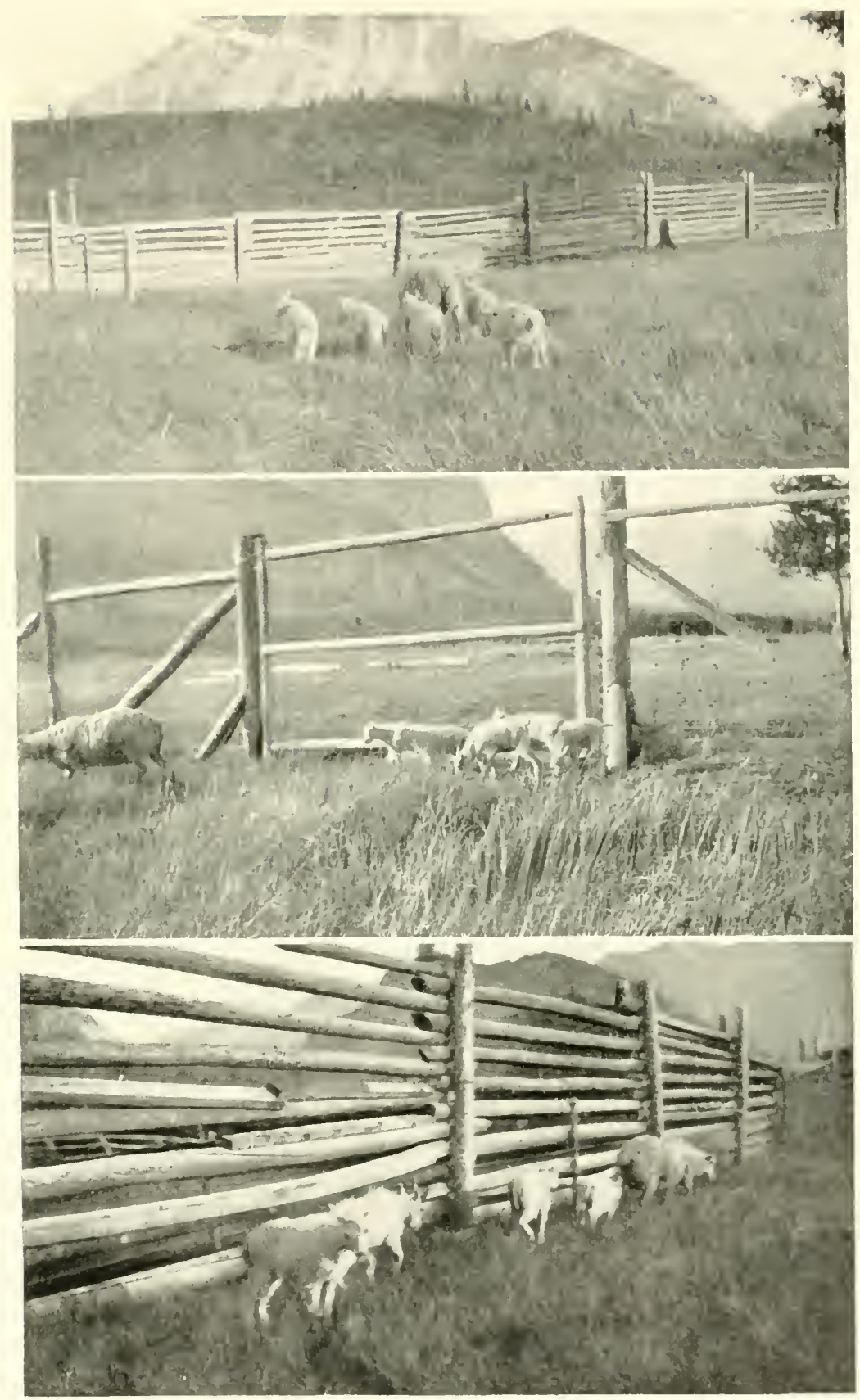

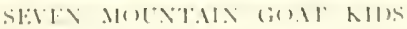

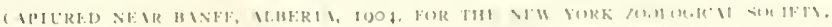


high up) in the munntains and in close contact with the eliffs where the goat lives. tonether with a copious supply of water. It all crents the comelitions are certainly lavorable. North of skagmaty goat do not extend inland much beyond the summit of the coast range, and (lo not again ocenr wntil the main Rockies are reached, humberls of miles to the east. The goat in these eastern monntains are, in all likelihoox. specifically distinct from the coast goat, as practically all the other mammals of these two distinct fanmal areas are separate species.

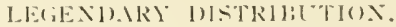

The writer has carefully traced out the legends regarding the uccurrence of goat in Colorado, Ltah, and California. There are persistent sturies about the existence of white goat in Colorado, which, when investigated seem to have their origin in some lomestic goat which are known to have escaped from captivity. It is. however, a certainty that Orammos has not existed in Colorato since the arrival of the white man, and there is no jroof of its previous existence there. This statement is matle after a full examination of the evidence.

The purpose of this paper has been to gather and summarize the known facts about this interesting animal and it has been necessary to cliscard a large amomt of clata contained in the literature of the subject. Statements by certain writers regarding the ex-

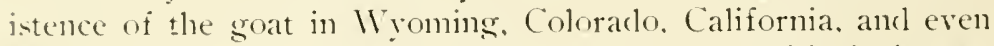
New Mexicn, are extremely misleading. It is positively known that 170 goat have ever existed on Mt. Shasta, although this mountain has feen a favorite locality for stories about mountain groat ancl the muthical ibex. The origin of these fables is easily traced to the former existence on Mt. Shasta of momtain sheep, the horns and bones of which are still occasionally found there. The straight horns of the mountain sheep ewe are probably responsible for most of these legends. It is bad enongh to suggest the occurrence of goat on Mt. Shasta, but it is utterly absurel to assert their existence on Mt. Whitney, 300 miles farther south, and it is still worse to inclucle in the range of the goat New Mexico or the barren coast mountains of sonthern Califurnia.*

The above examples will suffice to show the loose manner in

* See "Sport and Life in Western America and British Columbia," by A. W. Bailli -Grohman, page is 7 , London, 1900, and "The Wilderntss Hunter," page r 30 , by 'Theodore Romevelt. 


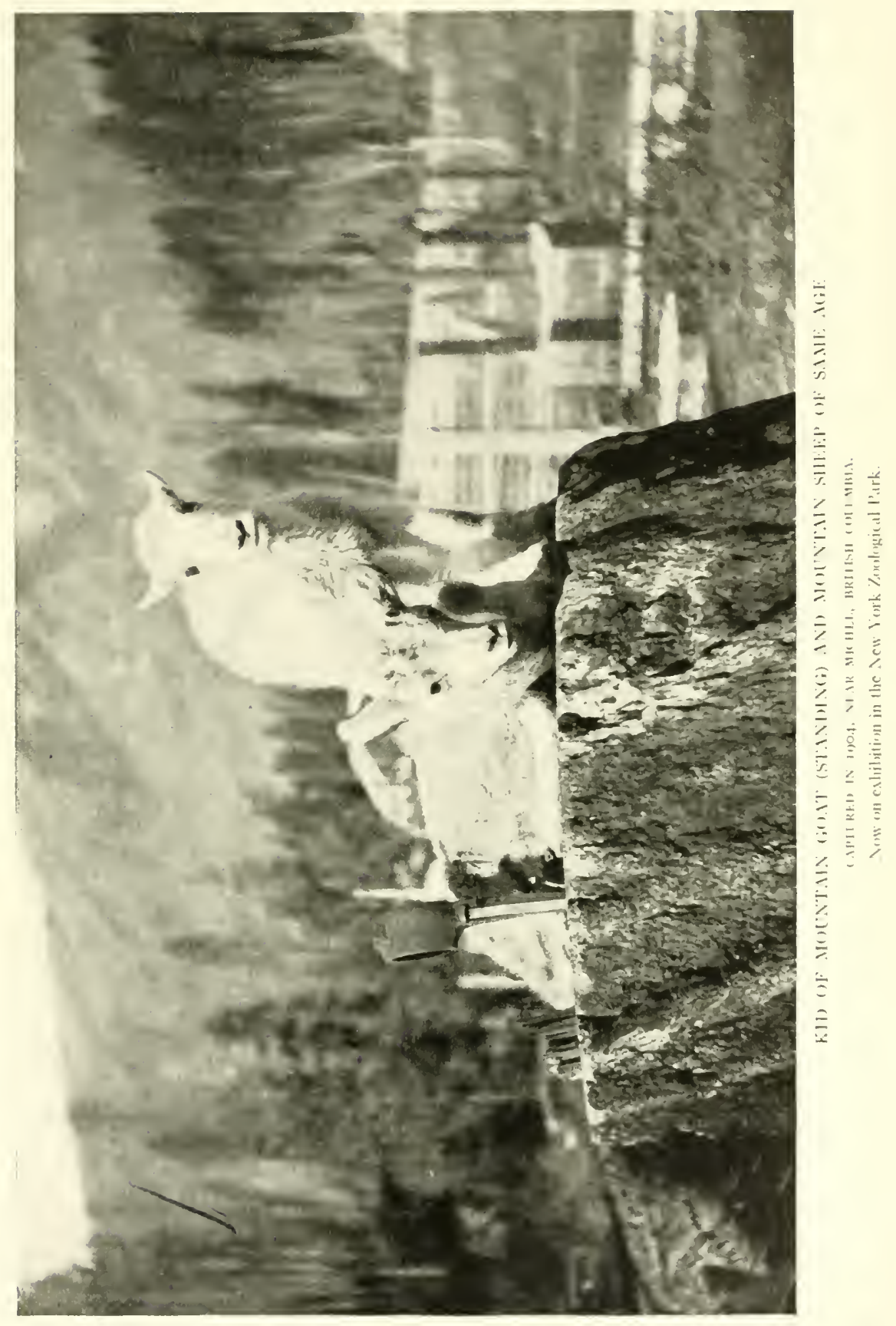


which this subject has been treated by writers who have not sifted the evidence sufficiently:

Within the Lnited States the mountain goat is only found in Iraho. Western Montana. Mashington, and Oregon. There is 170 evidence whatever of the white goat having existed in Myoming. In examining the rumors respecting the ocetrrence of goat one nutst remember that only a few years ago very little was known about this animal, and few people had seen it. In the south, escaped domestic goat and old mountain sheep ewes with bleached coats and straight horns. have probably been the basis of many such stories. In some places stucl animals have been mistaken for white goat and clsewhere, notably in Alaska. for the legendary ibex. Lntil the discovery and description of Dall's white sleep, in ISS f, all white anmals in the north were called goat and white mountain sheep meat is sold to-day in Dawson Citr restaurants mucler that name.

There is 110 reason whatever to believe that the limits of the distribution of the white goat were ever much different from what they are now, except in ontying localities along their southeru linits. The center of the greatest abundance of goat appears to be in the coast ranges in British Columbia and sonthern Alaska and it is here that they are found low down the mountain sides and often close to salt water.

\section{COMPARISON WITH SHEEP.}

It is due to ignorance of the character of the country inhabited by mountain goat that so much has been written about an alleged antipathy between Oreamnos and the mountain shcep. It is singular that writers should go so far afield as to conjure up an imaginary mutual hatred to account for the undoubted fact that sheep aind goat seldom live together. In some places, however, notably the Schesley Motntains, sheep and goat can be found on the same mountain side. Sheep belong to the rugged hills and lower slopes and at one time ranged far eastward into the plains wherever the character of the country was at all rough, as in the lilack Hills and in the Bad Lands of the upper Missouri.

The sleep is furthermore, a grass-eating animal, while the goat is a browser, finding his food mainly on the buds and twigs of the forests that grow to the very foot of the goat rocks. All through the goat country occur patches of forest and it is there that the goat is found, between timber-line and the snow fields. So far as we know the only grazing done by the goat, beyond 


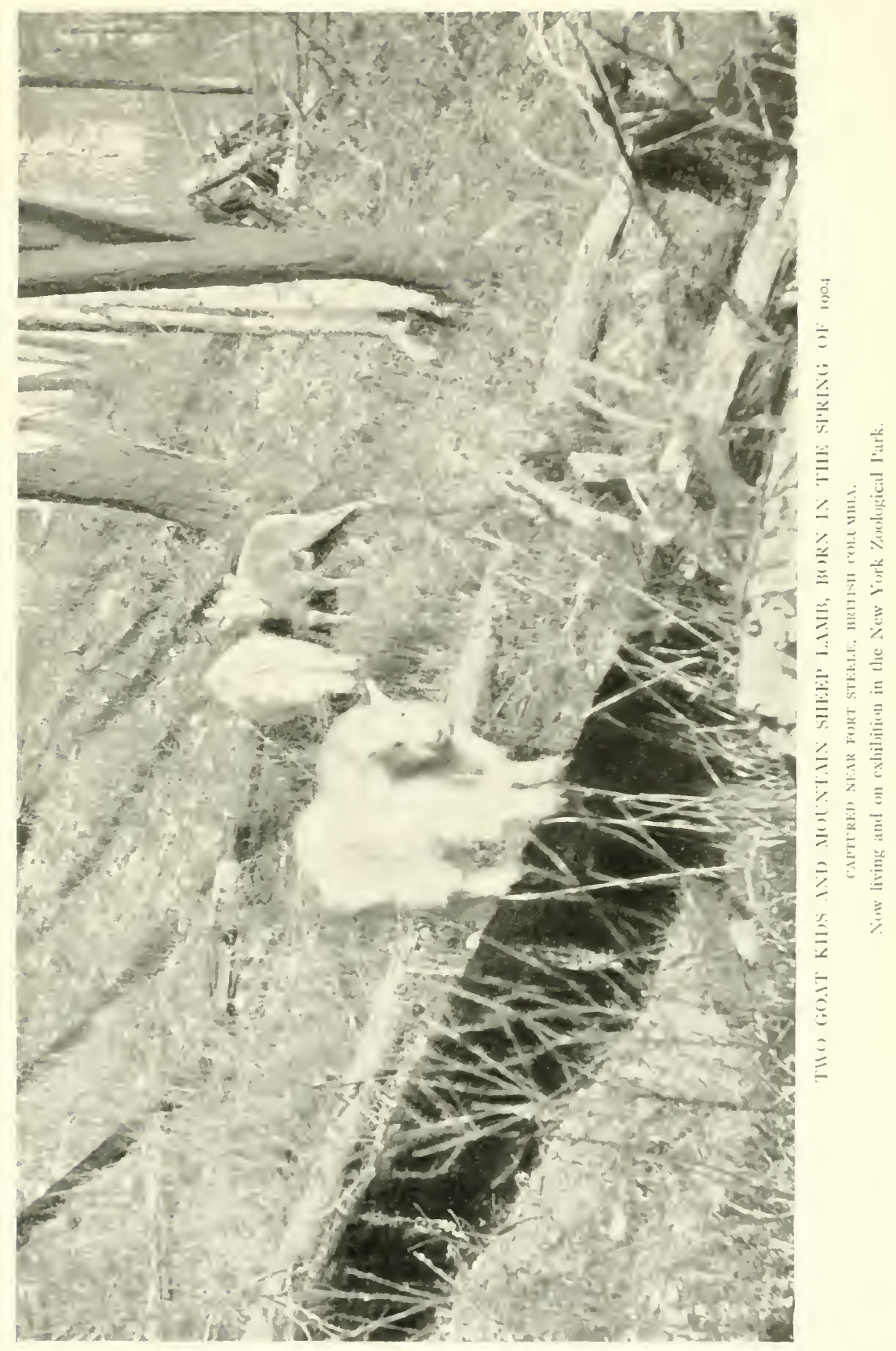


nibl)ling at small plants, is on the slicles when the grass first appears and it is probable that to this habit the greatest mortality of this animal is the, as many are killed each spring by the avalancles on these snow slicles.

The sleep is an active. Wary and Heet-footed animal, fully as well erfuipperl as the deer to escape by agility from its enemies and is not dependent for safety on a refuge berond the reach of other animals. The woat on the other hand. is heary powertul, clumsy. slow moring and somewhat stupid and does not dare to venture very far from its inacessifble rocks. It thrives among precipitous cliffs, which are everyhere known among hunters as "goat rocks" and are recosuizalsle as such at a slance.

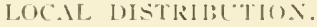

In a monntainous comntry it is perfectly easy to say where goat are to be fomnd, if there are any in the neighborhood. They desecurl, of conrse, into the upper limits of the forests. but always keep near to cliffs to which they can retire when attacked. Sometimes swin rivers and have been killed while crossing the Stickene far into the forests. Salt-licks have been found in the hillsides. where great holes have been eaten out by these animals. The tratils which lead to some of the licks in Piritish Columbia are Worn so (leeply as to resemble buffalo trails. Goat pass through the forests and lower slopes of the monntains in moving from one locality to another, but this of comrse, is exceptional. They sometimes swim rivers and have been killed while crossing the Stickine River in British Colmmbia, a wide and rapiel stream.

so complete is the protection the goat finds in broken rocks and precipices, that they are practically ut of danger from any animal approaching from below, except bear. which frepuently lic in wat for them and occasionally capture an wnwary indiviclual. The eagles take a rery heary toll from the young goat in the spring.

The difficulty of reaching the mommatin tops is, of conrse. a protection against man, but the conspicums color and the slow movements of the animal make it a comparatively easy rictim when once reached loy hard climbing.

\section{IV.ITER SEIPIS.}

The question of water supply on the mountains inhabited by goat has a most important bearing on the rlistribution of the animal. In a larese portion of the southern range of the goat, little 


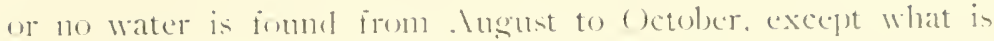
furnished by such show fields as persist throughout the year. All other animals can, during the dry season. venture down to the vallers and canons for water, but the wat seldom leares the rocks. eren for water. relving on the smow of the momtatin tops.

This fact alone. I belicre, is sufficient to accomnt for the absence of the goat, so often commenter on by hunters, in many portions of its range. where other conditions appear to be entirely suitable. In southern British Colmulia the weat river valleys, such as those of the Kootenay, the Colmmbia and the licater, rum almost north and south, and prevent communication from east to west between the grat inhabiting the arljacent momntans, while these same valleys offer no difficulties to the crossing of sheep and other large animals. Farther north in the stickine comntry wide valleys are sometimes crosied.

The presence or absence of water on the higher ricleses, taken together with the fact that the goat is not a rety restless or migratory animal, aceounts for many of the anomalies that are observed in its distribution. It is probable that in the comrse of its life the goat ranges orer a smaller territory than any other of our game amimals and muless seriomsly distubed does not venture far from its native haunts as long as the food supply lasts. They can msually be found day after day on the sime spot and goat have been watched, through glases, which apparently scarcely mosed for days at at time. () f course, in such a spot. food and water must be plentiful, and no danger threatening.

Nomg the Columbia River woat have been sometimes olserved to get into positions on the face of the cliffs. from which they apparenty combl not escalle. In spite of their weat strength and climbing abilits, their home must be an execptionally dangerous one and it is probable that many lose their lives thromento accilents.

In British Colmmbia, during the early summere the streams from the melting suow on the momutain tops are found in every draw and sulch. During this season small hands of females and kicls. or solitary males, are seattered crerrwhere in faromalole localities. from the mpler timber to the smmmits of the mommtains. Is the season atrances howerer ambl the snow-fed streams dry mp. the only water arablable is fomme in the latrer batsins where the sum has acemmlated in larege puantities. These basins becone the feeling gromme of the gont ame the rest of

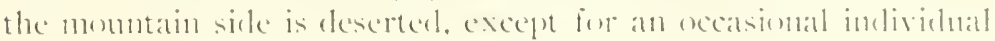




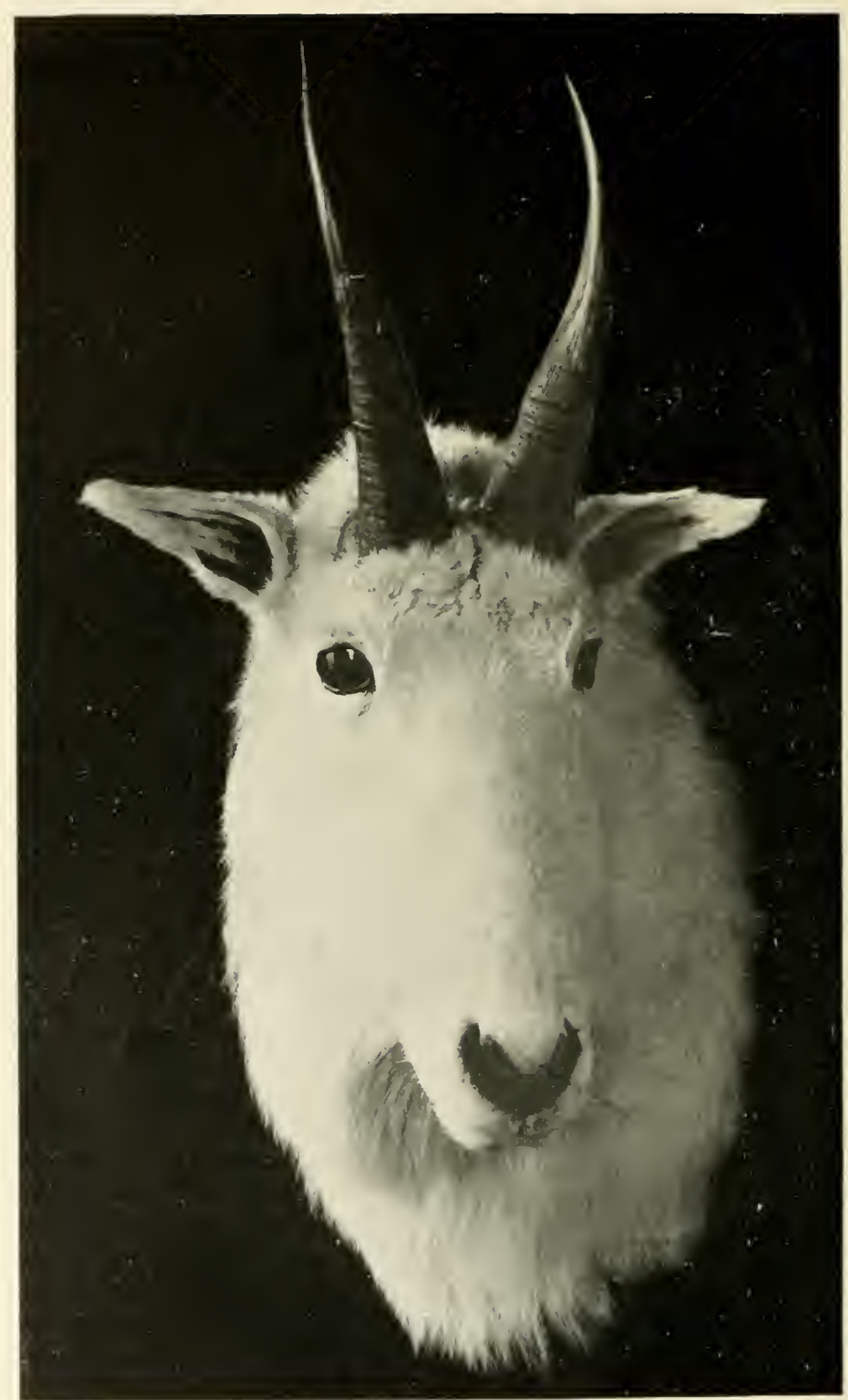

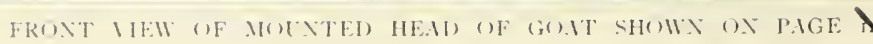
PRHPETY OF MAMISON GRANT.

(1) exhilition in the American Museum of Xiatural History 


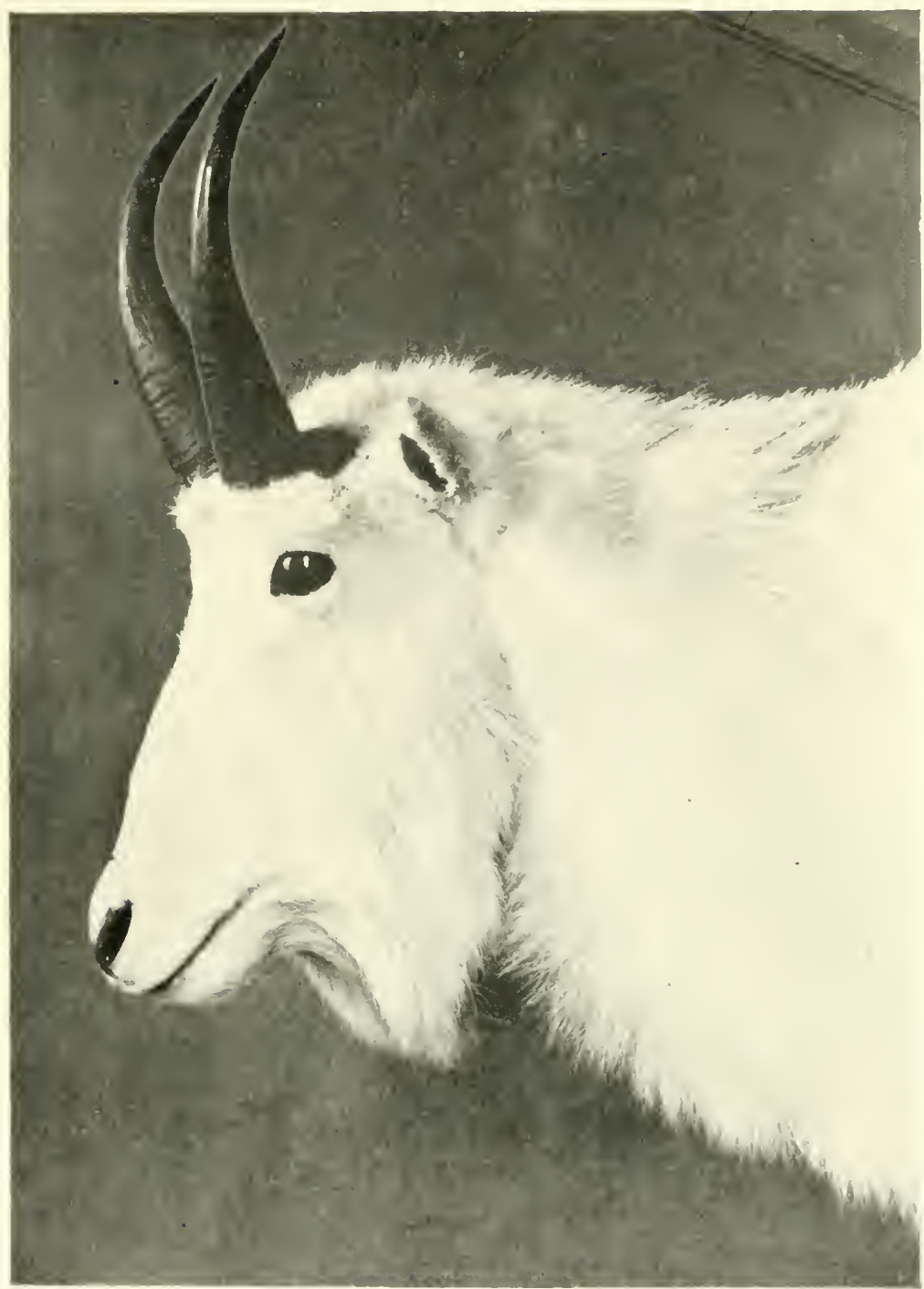

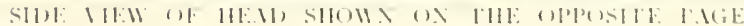

traveling alomg the summit from one such feceling groumel to anculler, or doring the attmm rutting seasom, when beth sexes are abmost comstamty on the move. Combeting two farorite

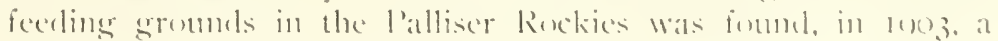


well beaten path along the stmmit-ridge, passing close to the snow fields and slowing constant nsager.

\section{WINTER R.NOIES.}

In winter the goat suffers from the severity of the storms on the monntain tops and the linit of its increase is, in the long run, dependent on the food supply available during this season. This is also true of most of our large gumals and the elimination of the weak takes place during the terrible blizzards of winter and carly spring.

In much of the southern range of the goat the use of the larger valleys for farming has nudoubtedly interfered seriously with their lower feeding grounds. While the loss of these winter ranges is more serious for other game, even the goat feels the approach of civilization. The high valleys, however, still remain nutuncher and a certain number of hardy individuals will winter successfully in close proximity to settlements if not too much hunterl. This is notably the case in the Bitter Root Valley, where goat are often found within sight of the town of Hamilton, Montana.

In winter the question of water supply is, of course, eliminated and at this season many ranges are well stocked with goat which, in snmmer, are deserted on account of lack of water. The goat travels so slowly that, aside from the danger of venturing far from the rocks, long daily journeys to and from a feeding ground are (juite inmpossible.

As to food supply, we are apt to think of the mountain tops as barren in comparison with the valleys ; but in a very momtainous region, such as British Columbia, the reverse is often true. ()n the higher mountain slopes and rilges are to be found the lest pasturage and the most smmy resting places. The valleys receive the sun for a much shorter portion of the day than do the higher ridges and while the mountain tops are above the fogs, mists and clonds often clarken the low conntry. It is noticeable that domestic cattle, sheep and horses in a mountainous country, are very partial to the high lands, seldom remaining voluntarily in the valleys and river bottoms. In such a country the first impulse of a grazing animal is to clinb high. Anyone who has tried to hunt horses which have strayed from camp, is apt to be familiar with this habit.

It is the inaccessible character of the country inhabited by the goat and not his wariness or agility, which has made goat hunt- 
ing a test of sportsmanship. ()nly these sound of wind and limb can renture after Oreammos. The first rule in goat hunting is to wo to the highest point that can be fomme and this point is apt to be very hichl.

\section{$11.1131 \% 5$.}

'The sight of a man does mot serionsly distmrls a goat and it seems (1) he of indifferent power of vision. Somnds affect it even less. The comstant falling of rocks and stomes and the rumble and breaking 11p of the glaciers, close to which it finds its home, has led the goat to distrust the warning of its ears. Shouting at a goat only arouses a slight euriosity and the report of a rifle bas scarcely more effect. The hunter may sometimes stand for an hour in plain view of a goat without listurbing it. hut its sense of smell is highly developed and the slightest trace of hmman scent will alarm it.

These characters, together with confidence in the inaccessible nature of its halutat, lorn of long experience with animals other than nuan, have all combines to give the goat its reputation for stupidity. It probably is stupid, but less so than would appear to those accustomed to the nervonsuess of other game anjmals. The goat, like the skink, has a serene reliance in its ability to protect itself and is accustomed to gaze with indifference at enemies who threaten it from below. The large males are not lacking in loravery and will savagely fight off a dog when attaclere. Stories are told of wounded goat attacking man when cornered, but most of the danger to the hunter lies in missing a foothold, or in the stones rolled down from above loy a flecing animal.

Got are marvelonsly tomgh and can carry more lead cren than a grizzly. It sometimes secms almost impossible to kill them and in some cases when hopelessly wommled, they show a tendency to throw themselves from a cliff. That this is a deliberate act on their part is generally believerl by goat hunters, but it is doulut ful whether it is nuore than a last desperate effort to get ont of harm's way.

Goat, like moose, are inclined to be solitary, but are often foume in small fanily sroups. They occasionally assomble in larger mumbers in some farorite feeding gromel. as 111any as twenty-seren having leen seen together. 


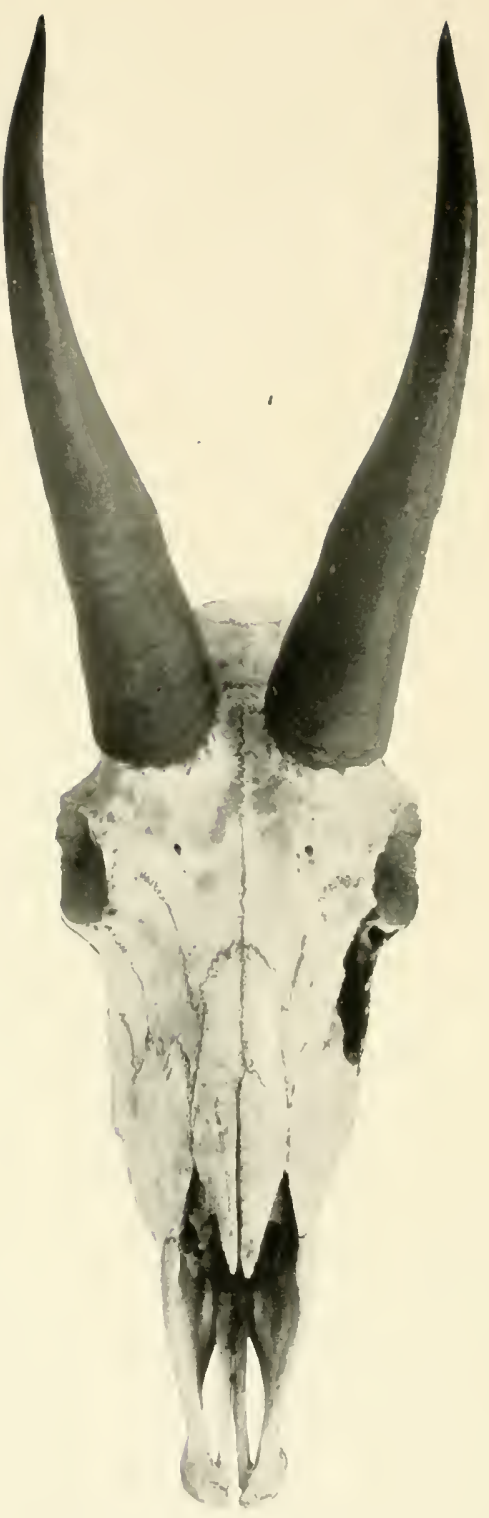

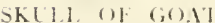

KILLED BY YADISUIN GRINT, SEPIEMBER, I()03,

Main Rocky .He untains, east side of Columbia River, scuth of Gołden, British Columbir. Measure. ments in inches: Right horn, $10_{4}^{1}$ inches; left, $10_{26}^{3}$ inches: spread of horns, $4{ }_{2}^{7}$ inches.

These measurements are the largest on record. with a known history. Samc specimen as on pages 20 and 27 . 


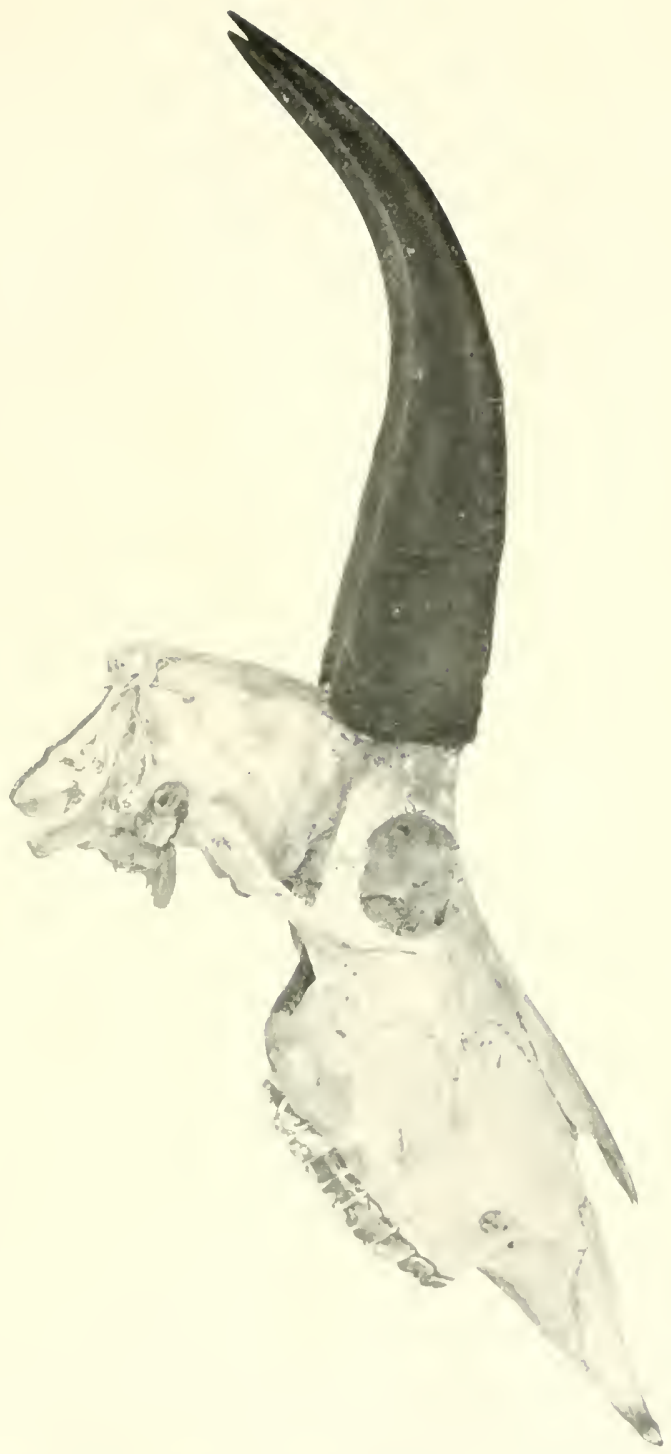

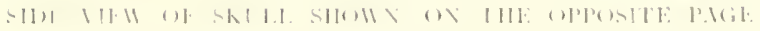


The strength of the soat is enormons and while its weight is far greater than one would at first suppose, it is a matter about which we lave little definite information. In average specimen from the Cascade Mountains appears to weigh about i 50 pounds. A six-year-old goat killed near Skagway, Alaska, showed an actual weight of 329 pounds. A much smaller animal killed at the same time and probably a female, weighed 250 pounds. Large goat from the main Kockies, in British Colmmbia and Schesley Mountains. have been estimated to weigh as high as 350 and too pounds. Mr. Paillie-Grohman publishes an account of a full grown male goat captured near Deerlodge, Montana, which was weighed after its capture and " was found to turn the scales at + So pounds!" " This, howerer, must be an error.

The size of the goat is emphasized by the long and shaggy coat. which at the shoulders rises in a hump. This, taken in connection with the low-carried head, gives the animal the appearance of a pigmy bison. Careful measurements of goat are hard to obtain, but authentic figures which were taken by $\mathrm{Mr}$. Stone, of four goat killed in August, ryoz, in the Schesley Mountains, British Colmubia, are to be found at the end of this article.

\section{HORNS. *}

The horns of the female are slightly longer and much more slender than those of the male. A little orer eleven inches appears to be the extreme limit of horns for the male. The longest horns known are from British Columbia, attaining a length of something over ten inches up to an extreme measurement of eleven and one-half, which appears to be the record. The horns from the litter Ront Monntains arerage at least an inch shorter, as do those from the coast ranges in the United States. Any horn measuring over ninc inches is to be considered of good size and anything over ten inches is rery exceptional. All measurenents of horns and antlers are subject to considerable variation, owing to the material of the tape and zeal of the man holding it and this must be taken into consideration in the measurements of record horns. In the measurement of the basal girth of sheep horns a variation of as much as an incl has been found to occni in the recorded size of the same horn taken by different persons, all quite conscientions in their efforts to be accurate.

* Ieatsurements of horns are given at the end of this paper. 
PROTECTION.

The mountain goat has probably a better chance of survival in a wild state than any other. Imeriean game animal, except posibly the Virginia deer. It is protected even from man by the extreme rugeedness of its mountain habitat and although it will probably be exterminated in certain localities, if given a moderate amount of protection it ean loblel its own throughout most of its range. Its history will probably be like that of the chamois in Europe, as the country grows more populated.

In some localities it is in great neerl of protection. In southern British Colmmbia, the ludians. who are not amenalue to the laws governing the white man, but are protected by treaty rights secures by the Dominion govermment, kill right and left with impunity. In Canala. even nore than in the United States, solicitule for the noble red man works great injury to all our same anmals. In the early lays, from motives of self-interest, the Indian may have been moderate in his killing, but, having abandoned his archaic weapons in favor of modern fire-arms, he is now an unmitigated butcher.

The Kootenays on the upper Columbia and the Stoneys on the east face of the Rocky Mountains in Alberta, are same murderers and it is the boast of the latter that no game can live where they hunt. In the interest of gance protection in British Columbia, it is greatly to be regretted that the enforement of stringent laws camnot be extended to the Indians. Curiously enough, many persons, who would ordinarily be friendly to game protection, have become so interested in the natives, that they advocate hunting privileges for Indians which they deny to the white man. under the mistaken impression that the Indian kilis only what he needs. The strange delusion has recently led to an attempt ly a benevolent Lniter States Senator to repeal the game laws for Alaska and leave that great game region to the merey of the native and meat hunter.

S.IIE OF (i.) IIE IIE.ALS.

The hunting of the Stoney Indians has been somewhat discouragerl by a wise law recently enacted in the Northwest Provinces. prolibiting the sale of gane heads. This law is especially beneficial to sheep, since the demand for heads of large rams has been steadily increasing. Oremmos has not suffered greatly from heal hunting, as its horns elo mot offer much of a tropher exeept 
when needed to complete a collection of American game animals. The marketing of gane heads cannot be too strongly condemned by sennine lunters and by those interested in the protection of wild animal life.

\section{IÑTRODECTION OF FOREIGN ANIAALS.}

In this comnection a word slould be said abont a proposition to establish chamois in the Rocky Mountains. Efforts to introduce European game, instead of protecting the native American animals, are constantly cropping out. Why anyone should prefer a chamois to the far finer native animal is somewhat of a mystery. Nature has provided for every portion of our conntry, mammals, birds and fish well adapted to the needs of the locality, and the introduction of foreign animals simply means, in case they survive, the crowding out of some native form.

In the East the monntain goat never can be more than an object of temporary curiosity; as he cannot long survive the rigors of onr Atlantic summer. A number of young goat have been captured in Pritish Columbia for exhilition in the New York Zoological T'ark, but while very docile, and taking readily to the milk of domestic ewes. they all died before shipment except the four now on exhibition at the Park. The proper place for the exhibition and breeding of monntain goat is in the Canadian National Park at Banff, Alberta, where there is an unsurpassed opportunity to secure and breed not only goat, but also monntain sheep, bison and even moose in their native environment.

\section{ACKNOWLEDGMENTS.}

The writer desires to acknowledge his indebtedness for assistance in the preparation of the above article to Mr. Charles Arthur Moore, Jr.. to Mr. Andrew J. Stone, to Dr. J. A. Allen, to Mr. Charles H. Townsend, to Mr. Wilfrid H. Osgood, and to members of the Geological Survey, motably Mr. A. H. Sylyester. 
MEASUREMENIS.

Four goat killed in the Schesley Mrountains of British Columbia, in . Iugnst, 1902. antl measured with extreme accuracy, ran als follows:

Total length, end of nose to end of tail vertelura .......... or

Tail vertebra ................

Tarsus . . . . . . . . . . . . .

Height at shoulder No. 43 . No. 44 . No.57. No ho.
inches inches inches inches

No. 57 was about a half-grown animal.

No. 60 was the largest specimen and its estimated weight was over too pounds.

Detail measurements in millimeters of No. Go * are as follows:

End of nose to lower corner of right eye. . . . . . . 20)

Encl of nose to bace of ear. . . . . . . . . . 207

End of nose to base of right horn. . . . . . . . . . . 205

Width of head just orer eyes............ I t7

Mirlth of nose above nostril.............. 65

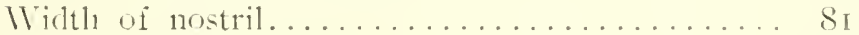

Greatest depth of head ................. 193

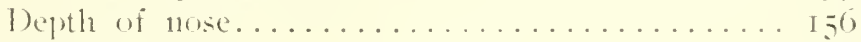

1)epth of chin.................... I 19

Tetween the eres................... I Io

Circumference of horn at hase. . . . . . . . . I 53

Length of horn. . . . . . . . . . . . . . . 2 2ro

Width between point of horns............210

Length of ear.................... 150

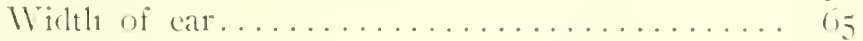

Length of beard................... I0

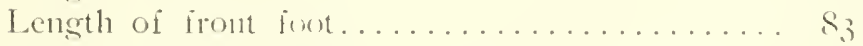

Width of front fort................

Extreme wielth of dew claws ontsiele.......... So

Length of front of front hoof ........... 52

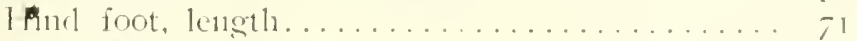

Hind foot, width..................

Length of lew claw.................. 52

IViclth of dew claws................. it

* No, to in garate shown un page lo. 
MEALLREMENTS UF MULNTTIN GOMT HORNS IN INCHES.

Four large specimens in the United States National Museum, Washington, D. C.. selected and measured by Madison Grant on February 4. 1905. gave the following dimensions:

$\begin{array}{ccc}\text { Kight. } & \text { Left. } \\ \text { o } 10 & 93 / 4 \\ \& & 81 / 2 & 81 / 2 \\ \delta & 858 & 8 I / 4 \\ \& & 758 & 73 / 4\end{array}$

Lake Chelan. Washington.

'Sawtooth Mountains, Idaho.

Fifteen specimens in the American Museum of Natural History, New York City, were measured by Dr. J. A. Allen, with the following result :

Right. Left. Spread.

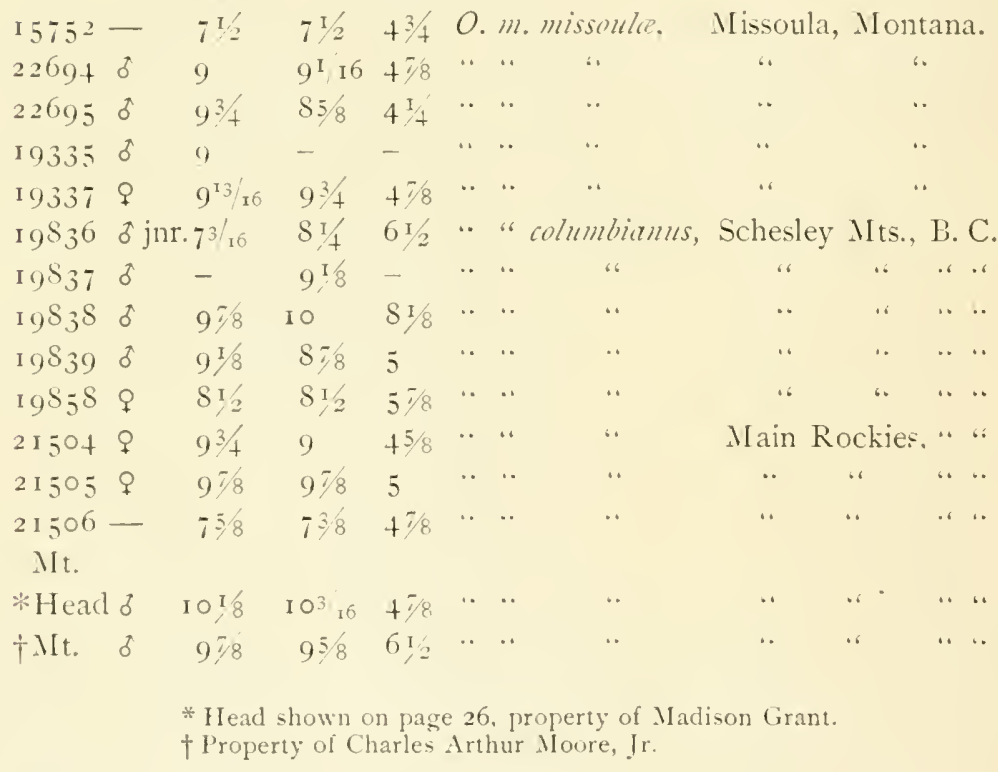






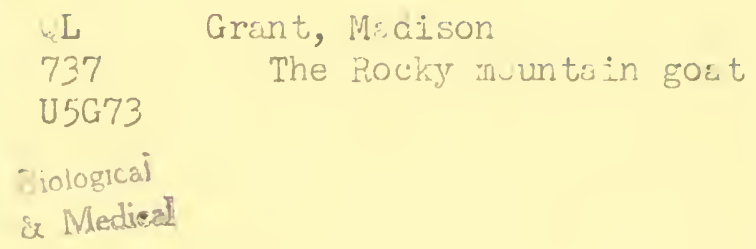

PLEASE DO NOT REMOVE CARDS OR SLIPS FROM THIS POCKET UNIVERSITY OF TORONTO LIBRARY 


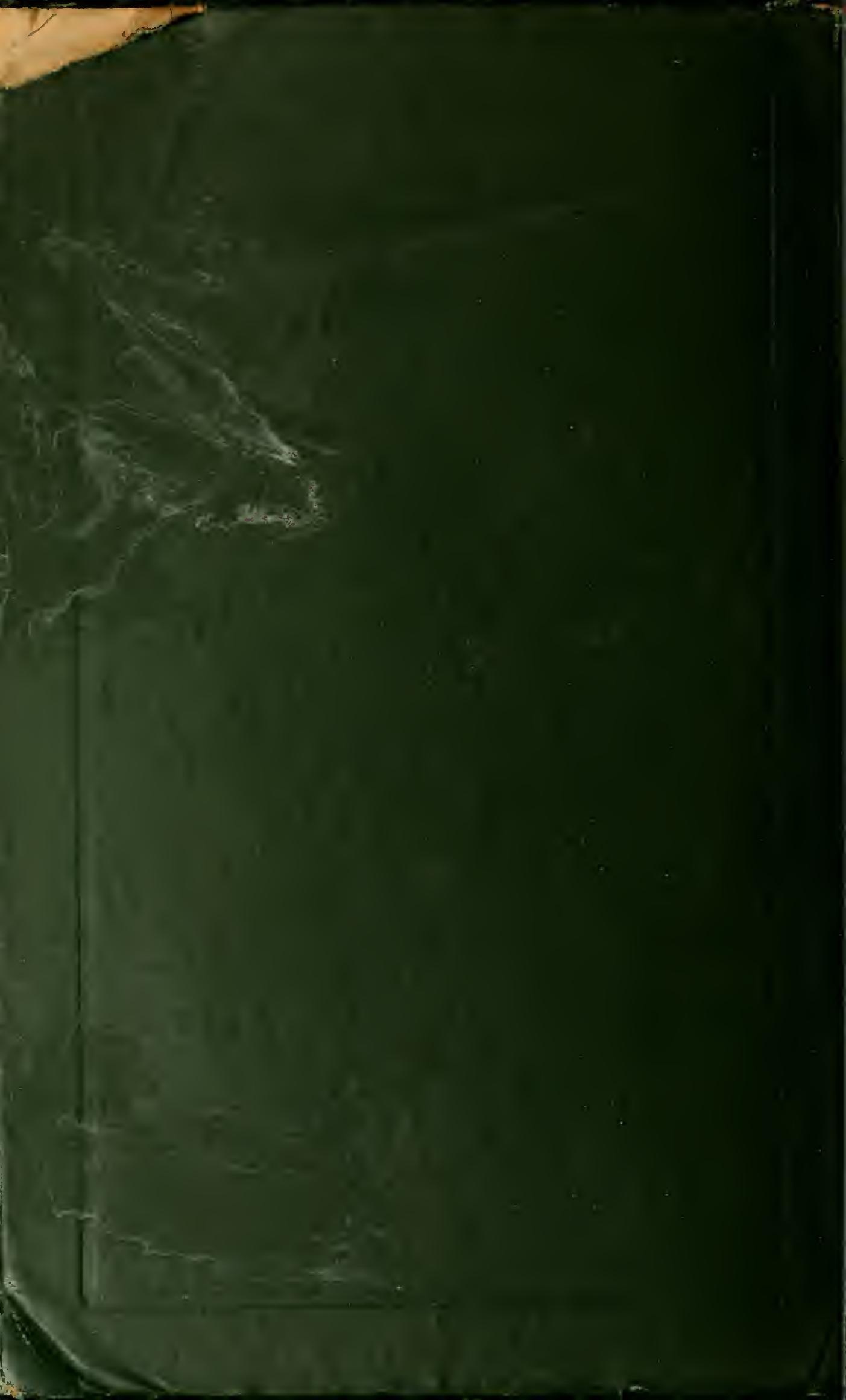

